\title{
Stress, anxiety, and psychotic experiences in adults with autism spectrum disorder
}

Citation for published version (APA):

van der Linden, K. F. J. T. (2021). Stress, anxiety, and psychotic experiences in adults with autism spectrum disorder: an observational study in the context of daily life. [Doctoral Thesis, Maastricht University]. Gildeprint Drukkerijen. https://doi.org/10.26481/dis.20211011kl

Document status and date:

Published: 01/01/2021

DOI:

$10.26481 /$ dis.20211011k

Document Version:

Publisher's PDF, also known as Version of record

\section{Please check the document version of this publication:}

- A submitted manuscript is the version of the article upon submission and before peer-review. There can be important differences between the submitted version and the official published version of record.

People interested in the research are advised to contact the author for the final version of the publication, or visit the DOI to the publisher's website.

- The final author version and the galley proof are versions of the publication after peer review.

- The final published version features the final layout of the paper including the volume, issue and page numbers.

Link to publication

\footnotetext{
General rights rights.

- You may freely distribute the URL identifying the publication in the public portal. please follow below link for the End User Agreement:

www.umlib.nl/taverne-license

Take down policy

If you believe that this document breaches copyright please contact us at:

repository@maastrichtuniversity.nl

providing details and we will investigate your claim.
}

Copyright and moral rights for the publications made accessible in the public portal are retained by the authors and/or other copyright owners and it is a condition of accessing publications that users recognise and abide by the legal requirements associated with these

- Users may download and print one copy of any publication from the public portal for the purpose of private study or research.

- You may not further distribute the material or use it for any profit-making activity or commercial gain

If the publication is distributed under the terms of Article $25 \mathrm{fa}$ of the Dutch Copyright Act, indicated by the "Taverne" license above, 


\section{Summary}

The overall aim of this thesis is to identify underlying mechanisms and potential risk factors that may contribute to the emergence of co-occurring psychiatric symptoms in adults with autism spectrum disorder (ASD). This was done with daily life electronic self-monitoring studies, based on the Experience Sampling Method (ESM). The main focus of the present thesis is to investigate daily life stress, psychotic experiences (PE), and anxiety in the natural flow of daily life.

The first part of chapter 1, provides general information on ASD and differences between males and females with ASD are addressed. In the second part, the prevalence of negative affect, PE, and social anxiety are discussed in individuals with ASD. Also, the role of daily life stress on (i) negative affect (emotional stress reactivity), (ii) the stress hormone cortisol (biological stress reactivity), and (iii) PE (psychotic stress reactivity) is explained. The last part of this chapter addresses the use of the ESM and provides an overview of research investigating emotional and biological stress, PE, and social anxiety with this method.

Chapter 2 presents a systematic review of the literature on emotional and biological stress in individuals with ASD across the lifespan. All reviewed studies found higher emotional stress levels in children, adolescents, and adults with ASD compared to individuals without ASD (i.e., controls). However, results regarding biological stress were inconclusive. That is, studies investigating cortisol response to a stressor found a similar, increased, or decreased cortisol response in children and adolescents with ASD compared to controls. Moreover, an equal number of studies found a similar or flattened diurnal cortisol rhythm in children/adolescents with ASD relative to controls. And most studies did not find group differences regarding the presence of the cortisol awakening response (i.e., an increase of cortisol levels within approximately 30 minutes after awakening). Although studies on adults with ASD are scarse, a comparable cortisol response and diurnal rhythm was found relative to controls. Lastly, the majority of studies did not find an association between emotional and biological stress. In conclusion, these findings show the need to screen for emotional stress levels, as well as the need for stress management in the clinical support of individuals with ASD. Moreover, studies with large enough samples to study specific subgroups within the ASD population are needed to investigate cortisol response and cortisol rhythm. Regarding the latter, future studies should aim at collecting more cortisol measurements for a longer period, preferably combined with momentary emotional stress measurements.

An increased emotional and a disturbed biological stress response to daily stressors has been observed in individuals with several psychiatric disorders. However, to date this has not yet been investigated in adults with ASD. Therefore, the ESM study in chapter 3 compared associations between daily life stressors (activity-related, event-related, and social stress) and (i) negative affect (i.e., emotional stress reactivity), and (ii) cortisol levels (i.e., biological stress reactivity) in males and females with ASD and controls. The results showed elevated daily life stressors and negative affect, but similar cortisol levels, in adults with ASD compared to controls. Multilevel models demonstrated stronger associations between negative affect and unpleasant events or activities, but not social stress, in adults 
with ASD, i.e., an increased emotional stress reactivity. However, biological stress reactivity did not differ between the groups and there were no differences between males and females in emotional and biological stress reactivity. Altogether, the findings demonstrated a stronger emotional, but not biological, stress response to minor daily stressors in males and females with ASD than in controls. The heightened emotional stress reactivity in adults with ASD highlight the importance of stress reduction in this population.

It is well-known that the personality trait neuroticism is associated with increased emotional stress reactivity but data in adults with ASD is absent. Additionally, there is some evidence for increased negative affect when with less familiar people in adults with ASD. However, to date it is not yet known whether neuroticism plays a role in this association. The ESM study in chapter 4 was the first study to compare interactions between neuroticism and (i) daily life stress, and (ii) social contexts (i.e., being alone, with familiar, and less familiar people) in models of negative affect in adults with ASD and controls. Analyses showed markedly higher neuroticism levels in participants with ASD, and those with ASD who scored high on neuroticism showed a significantly stronger association between increased negative affect and unpleasant activities or social stress than those with low neuroticism scores.

Furthermore, the association between neuroticism and negative affect was stronger when adults with ASD were with less familiar people compared with being alone or with familiar people. No consistent corresponding interactions were found in controls. In conclusion, neuroticism moderates the association between appraised stress and negative affect as well as the association between social context and negative affect in adults with ASD. The results imply that neuroticism levels may explain some part of the heterogeneity in the ASD population and should, therefore, be targeted during the clinical treatment of adults with ASD.

Current literature on PE in individuals with ASD is limited with an inconsistent pattern of results. Moreover, research on the impact of daily life stress or negative affect on PE in ASD is absent. The ESM study in chapter 5, examined lifetime and momentary PE in adult males and females with ASD and controls. First, a retrospective questionnaire was used to examine the frequency of lifetime subclinical positive, negative, and depressive symptoms and accompanying distress. Adults with ASD reported more lifetime negative and depressive symptoms, but similar levels of PE (i.e., positive symptoms), than controls. Also, higher levels of accompanying distress were found in participants with ASD for each symptom scale. The ESM data showed markedly higher momentary PE levels in the ASD group. Additionally, participants with ASD showed a significantly stronger association between momentary PE and unpleasant events compared to controls, i.e., an increased psychotic stress reactivity. This group difference was not found for unpleasant activities, social stress, or negative affect. Also, no significant differences were found between male and female outcomes. In sum, adults with ASD reported higher levels of distress related to (lifetime) PE and an increased psychotic stress reactivity in response to unpleasant events. This may lead to a vicious cycle where adults with ASD may feel distressed by their PE, which, in turn, increases the frequency and intensity of PE. Stress prevention may be one way to disrupt this cycle. 
There is a need for more data on social anxiety symptoms in adults with ASD. Also, present data on associations between momentary anxiety and different types of social context is preliminary and factors of influence on social anxiety, such as self-esteem and negative appraisals of social company are still unknown. In the last ESM study of this thesis, we first compared trait social anxiety levels between adults with ASD and controls. Next, associations between ESM momentary anxiety and three social contexts were examined. Lastly, we investigated associations between ESM momentary anxiety and (i) self-esteem, and (ii) negative appraisals for several types of social contexts. The results in chapter 6 demonstrated higher trait social anxiety levels in adults with ASD relative to controls. Furthermore, the ASD group reported higher levels of momentary anxiety and negative appraisals of social company, but lower self-esteem levels, compared to controls. Adults with ASD showed significantly higher momentary anxiety levels for each type of social context compared to controls. The highest momentary anxiety levels in the ASD group were found when being with less familiar people, which was significantly different from being alone or being with familiar people. Although controls had the highest momentary anxiety levels when being alone, there were no significant differences between the three social contexts. Moreover, significant associations between momentary anxiety and low selfesteem were shown for all three social contexts in both groups, with the strongest association for being with less familiar people in the ASD group and for being alone in controls. Negative appraisals of company was significantly associated with momentary anxiety in both groups, though not modified by social context. Current findings underline the need to pay attention to the high prevalence of trait social anxiety levels in adults with ASD and the importance of targeting self-esteem and negative appraisals of social company in the treatment of social anxiety in adults with ASD was demonstrated.

Finally, chapter 7 brings the findings of all previous chapters together in a general discussion on the main themes of this thesis: emotional and biological stress, PE, and social anxiety. Additionally, strengths and limitations, ideas for future research, and clinical implications are provided 


\section{Samenvatting}

Het doel van dit proefschrift is om onderliggende mechanismen en potentiele risicofactoren te onderzoeken die mogelijk van invloed zijn op het ontstaan van comorbide psychiatrische symptomen bij volwassenen met een autismespectrumstoornis (ASS). Waarbij de huidige thesis zich specifiek richt op het bestuderen van stress, psychotische ervaringen en sociale angst in het dagelijks leven. Dit wordt gedaan door middel van elektronische zelfmonitoring studies, gebaseerd op de Experience Sampling Method (ESM).

Hoofdstuk 1 betreft de inleiding van het proefschrift. In het eerste gedeelte van dit hoofdstuk wordt uitleg gegeven over de diagnose ASS en wordt ingegaan op de verschillen tussen mannen en vrouwen met ASS. Het tweede gedeelte richt zich op de prevalentie van depressie/negatieve emoties, psychotische ervaringen en sociale angst bij personen met ASS. Daarnaast wordt ingegaan op de invloed van stress op veranderingen in (i) negatieve emoties (emotionele stressreactiviteit), (ii) het stresshormoon cortisol (biologische stressreactiviteit) en (iii) psychotische ervaringen (psychotische stressreactiviteit). Het laatste gedeelte van dit hoofdstuk richt zich op het gebruik van de ESM en biedt tevens een overzicht van bestaand ESM-onderzoek naar emotionele en biologische stress, psychotische ervaringen en sociale angst.

Hoofdstuk 2 bestaat uit een systematische review van de literatuur over emotionele en biologische stress bij personen met ASS. Alle studies in deze review vonden hogere emotionele stressniveaus bij kinderen, adolescenten en volwassenen met ASS in vergelijking met personen zonder ASS (ofwel de controlegroep). Uitkomsten met betrekking tot biologische stress waren echter minder concreet. Oftewel, onderzoek naar cortisolniveaus in reactie op een stressor liet zowel een gelijke, verhoogde als verminderde cortisolreactie zien bij kinderen/adolescenten met ASS in vergelijking met controles. Verder observeerden evenveel studies een gelijk of afgevlakt dagritme bij kinderen/adolescenten met ASS ten opzichte van controles. Daarnaast vonden de meeste studies geen groepsverschillen in cortisolniveaus in de ochtend (de hoogste cortisolpiek gedurende de dag is ongeveer 30 minuten na het wakker worden, dit wordt de 'Cortisol Awakening Response' genoemd). Ondanks dat studies bij volwassenen met ASS beperkt zijn, vonden deze studies geen significante groepsverschillen in cortisolreactie en dagritme. Tenslotte vond het grootste gedeelte van de studies geen samenhang tussen emotionele en biologische stress. Samenvattend laat deze review het belang van emotionele stressreductie zien bij personen met ASS. Toekomstige studies worden geadviseerd om cortisolniveaus te meten bij verschillende subgroepen in de ASS-populatie (zoals participanten met ASS en een angststoornis of depressie). Verder wordt geadviseerd om het cortisol dagritme intensiever en gedurende een langere periode te meten, bij voorkeur in combinatie met emotionele stressniveaus in het moment.

Een verhoogde emotionele of een verstoorde biologische reactie op stress in het dagelijks leven is aangetoond bij personen met diverse psychiatrische stoornissen. Dit is echter nog niet eerder onderzocht bij volwassenen met ASS. Om die reden zijn in de ESM-studie in hoofdstuk 3 associaties vergeleken tussen drie stressoren (sociale stress, onplezierige 
gebeurtenissen en onplezierige activiteiten) en (i) negatieve emoties (emotionele stressreactiviteit), en (ii) cortisolniveaus (biologische stressreactiviteit) bij mannen en vrouwen met ASS en controles. De resultaten lieten zien dat volwassenen met ASS meer stress en negatieve emoties rapporteerden dan controles, maar de cortisolniveaus waren gelijk. De analyses toonden een sterkere samenhang tussen negatieve emoties en onplezierige gebeurtenissen en activiteiten in de ASS-groep dan de controlegroep, dit gold echter niet voor sociale stress. Kortom, we vonden een verhoogde emotionele stressreactie (dus een toename aan negatieve emoties) op onplezierige gebeurtenissen en activiteiten bij volwassenen met ASS in vergelijking met controles. De resultaten toonden geen groepsverschillen voor biologische stressreactiviteit en ook werden er geen manvrouwverschillen gevonden voor zowel emotionele als biologische stressreactiviteit. Samenvattend vonden we een sterkere emotionele, maar geen biologische, stressreactiviteit bij mannen en vrouwen met ASS in vergelijking met controles. De verhoogde emotionele stressreactiviteit in de ASS-groep benadrukt het belang van het verminderen van emotionele stress bij deze populatie.

Het is bekend dat de persoonlijkheidstrek neuroticisme samenhangt met een verhoogde emotionele stressreactiviteit, data bij volwassenen met ASS ontbreekt echter tot op heden. Tevens zijn er enkele aanwijzingen dat er sprake is van een toename van negatieve emoties bij volwassenen met ASS wanneer zij in het gezelschap zijn van mensen die zij minder goed kennen. Op dit moment is het niet bekend of neuroticisme een rol speelt in deze samenhang. De ESM-studie in hoofdstuk $\mathbf{4}$ heeft het effect van neuroticisme onderzocht op de samenhang tussen negatieve emoties en (i) dagdagelijkse stressoren, en (ii) drie sociale contexten (alleen zijn, in het gezelschap van bekenden, of minder bekende personen) bij volwassenen met ASS en controles. De resultaten toonden significant hogere neuroticisme niveaus in de ASS-groep. Ook werd een significant sterkere samenhang gevonden tussen negatieve emoties en onplezierige activiteiten of sociale stress bij volwassenen met ASS en een hoge neuroticisme score in vergelijking met volwassenen met ASS en een lage neuroticisme score. Participanten met ASS en een hogere mate van neuroticisme rapporteerden dus een verhoogde emotionele stressreactiviteit. Verder vonden we een sterkere samenhang tussen neuroticisme en negatieve emoties wanneer volwassenen met ASS zich in het gezelschap van minder bekenden personen bevonden dan wanneer zij alleen waren of met bekenden. Deze verschillen werden niet geobserveerd in de controlegroep. Kortom, neuroticisme modereert emotionele stressreactiviteit evenals de associatie tussen sociale context en negatieve emoties bij volwassenen met ASS. Deze resultaten impliceren dat neuroticisme niveaus mogelijk een deel van de heterogeniteit in de ASS-populatie kunnen verklaren. Om deze reden is het van belang om deze persoonlijkheidstrek mee te nemen in de behandeling van volwassenen met ASS.

Onderzoek naar psychotische ervaringen bij personen met ASS is relatief beperkt.

Daarnaast is er geen bestaand onderzoek naar het effect van stress of negatieve emoties op psychotische ervaringen bij deze doelgroep. Het ESM-onderzoek in hoofdstuk 5 richt zich op de aanwezigheid van psychotische ervaringen bij mannen en vrouwen met ASS en controles, zowel ooit als in het huidige moment. Eerst is een retrospectieve vragenlijst 
gebruikt om de frequentie te onderzoeken van subklinische positieve, negatieve en depressieve symptomen (dit zijn (nog) niet zichtbare symptomen) en de daarmee gepaard gaande stress die men heeft ervaren. De resultaten toonden dat volwassenen met ASS meer negatieve en depressieve symptomen, maar evenveel positieve symptomen (ofwel psychotische ervaringen), rapporteerden dan controles. Verder rapporteerden zij meer stress gepaard gaand met depressieve, negatieve, als positieve symptomen dan controles. Dus ondanks dat er geen groepsverschil was voor de frequentie van psychotische ervaringen (positieve symptomen), ervaarden volwassenen met ASS wel meer stress wanneer deze symptomen aanwezig waren. Vervolgens is de ESM gebruikt om psychotische ervaringen in het dagelijks leven te onderzoeken. We vonden significant meer psychotische ervaringen in de ASS-groep. Ook werd een sterkere samenhang gevonden tussen psychotische ervaringen en onplezierige gebeurtenissen in de ASS-groep in vergelijking met de controlegroep, oftewel een verhoogde psychotische stressreactiviteit. Er werden geen groepsverschillen gevonden in de samenhang tussen dagdagelijkse psychotische ervaringen en onplezierige activiteiten, sociale stress of negatief affect. Daarnaast zijn geen significante verschillen gevonden tussen mannen en vrouwen. Samenvattend rapporteerden volwassenen met ASS meer stress wanneer zij ooit psychotische ervaringen ervoeren. Ook rapporteerden zij een verhoogde psychotische reactiviteit bij onplezierige gebeurtenissen in het dagelijks leven. Dit kan leiden tot een vicieuze cirkel, waarbij volwassenen met ASS, stress ervaren door de aanwezigheid van psychotische ervaringen, wat vervolgens kan leiden tot een toename in frequentie en intensiteit van deze ervaringen. Stresspreventie kan een manier zijn om deze negatieve cirkel te doorbreken.

Er is behoefte aan meer data over sociale angst symptomen bij volwassenen met ASS. Bovendien zijn onderzoeken naar associaties tussen angst in het dagelijks leven en verschillende sociale contexten enkel nog in de verkennende fase. Verder is er bij deze doelgroep nog geen onderzoek gedaan naar de invloed van bekende risicofactoren voor het ontstaan en onderhouden van sociale angst, te weten zelfbeeld en negatieve waarderingen van gezelschap. In de laatste studie van dit proefschrift is onderzoek gedaan naar sociale angst trekken bij volwassenen met ASS en controles. Vervolgens zijn, door middel van de ESM, associaties vergeleken tussen angst en sociale contexten. Tenslotte zijn associaties tussen angst en (i) zelfbeeld, en (ii) negatieve waarderingen van gezelschap onderzocht tijdens verschillende sociale contexten. In de studie in hoofdstuk 6 werden significant meer sociale angst trekken gevonden bij volwassenen met ASS dan bij controles. Daarnaast toonden de ESM-data een hogere mate van angst en negatieve waarderingen van gezelschap, maar een lager zelfbeeld, bij volwassenen met ASS in vergelijking met controles. De ASS-groep rapporteerde significant hogere angstniveaus dan controles voor alle sociale contexten, maar de angst was het hoogst wanneer zij met minder bekenden waren dan wanneer zij alleen waren of met bekenden. Ondanks dat de participanten in de controlegroep de hoogste angstniveaus rapporteerden wanneer zij alleen waren was er geen significant verschil tussen de drie sociale contexten. Een significante samenhang tussen laag zelfbeeld en angst werd gevonden voor alle drie de sociale contexten in beide groepen. Bij de ASS-groep werd de sterkste samenhang aangetoond in het gezelschap van 
minder bekenden. Terwijl controles de sterkste samenhang rapporteerden wanneer zij alleen waren. Tenslotte vonden we een significante samenhang tussen negatieve waardering van gezelschap en angst in beide groepen, maar dit werd niet gemodereerd door sociale context. De resultaten laten zien dat het belangrijk is om aandacht te besteden aan de hoge sociale angst niveaus bij volwassenen met ASS. Daarnaast wordt geadviseerd aandacht te hebben voor de invloed van zelfbeeld en negatieve waardering van gezelschap tijdens de behandeling van angst bij deze doelgroep.

Tenslotte, in hoofdstuk 7 worden alle bevinden van de eerdere hoofdstukken samengevoegd in een algemene discussie over de hoofdthema's van dit proefschrift. De sterktes en zwaktes van de onderzoeken in deze thesis worden besproken, tezamen met ideeën voor toekomstig onderzoek en implicaties voor de klinische praktijk. 